\title{
Emission of selected exhaust compounds in jet engines of a jet aircraft in cruise phase
}

Nowadays, air transport is in an intense development phase. In order to optimize air communication and make it even more economical and environmentally friendly, attempts are made to undertake such activities as, e.g., SESAR project, which aims to develop and implement a modern ATM system. One of the parts of this project is the research on minimizing fuel consumption and emissions of pollutants in the engine exhausts. In the paper there is therefore presented the methodology for determining emission of those pollutants for the longest stage of the flight - the cruise phase. First, the value of the thrust required for the flight of an exemplary aircraft was determined, and then the values of the engines trust and specific fuel consumption were computed. Additionally, it was necessary to determine the Emission Indexes (EI) of $\mathrm{CO}, \mathrm{NO}_{x}, \mathrm{HC}$ and $\mathrm{CO}_{2}$ for the cruise phase, based on known such indexes for the LTO. Total emissions of these pollutants for the mission adopted to conduct research - a $1000 \mathrm{~km}$ long cruise - were determined. These emissions were computed for the exemplary aircraft per one kilometre, as well as per one hour of flight for various cruising altitudes and flight speeds.

Key words: jet engine, emission, fuel consumption, cruise phase, ATM, SESAR

\section{Introduction}

Air transport is the most modern and the most dynamically developing branch of transport. Unfortunately, it also brings a negative impact on the natural environment and the population living in areas of high traffic intensity. This impact is mainly caused by the emission of noise and harmful substances, resulting from the combustion of fossil fuels by aircrafts engines.

The negative impact of air transport is the stronger the more intensive air traffic occurs in a given area. Europe is a unique region on Earth because of to the very high population density and high intensity of flights performed on its territory. In 2015, more than 9.9 million IFR operations were carried out in Europe and forecasts predict their growth by 16 percent by 2022 (Fig. 1) [3]. Currently, around 27,000 controlled flights take place in the European airspace every day. Europe is facing an airspace capacity crisis, as it is predicted that the number of flights will increase by as much as $50 \%$ in the next 10-20 years [3].

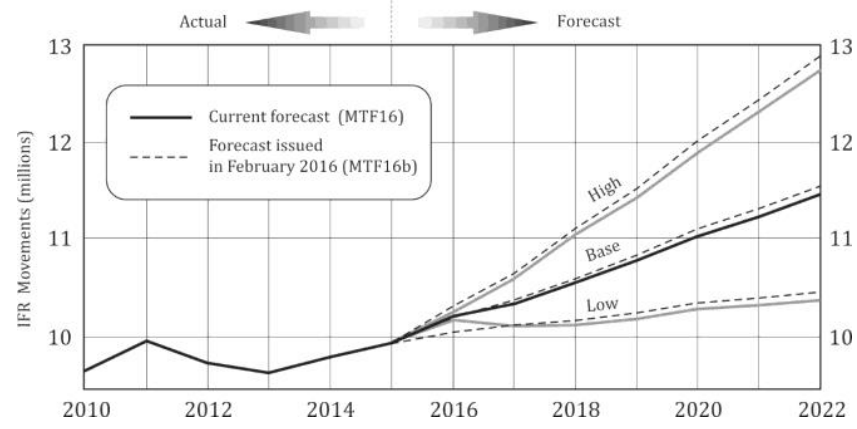

Fig. 1. A seven-year forecast for total Europe flight movements [3]

Historically, Europe consisted of a number of countries that did not create uniform political, economic or demographic systems. Along with the development of closer political and economic cooperation within the European Union, the efforts have been made to harmonize the rules of
Air Traffic Control (ATC) and Air Traffic Management (ATM), which has led to creation of a Single European Sky (SES) over Europe. Despite those activities, the ATC and ATM systems in Europe are fragmented and dominated by local ANSP (Air Navigation Service Providers) that have a monopoly for the running the ATC and ATM services. The border division of the airspace has made the European ATC and ATM system a kind of a mosaic of national ATC and ATM systems [9, 10, 11, 15].

The answer to these problems was the launch of the SESAR program (Single European Sky ATM Research), which is a technological pillar of the SES. The aim of this program is to improve ATM system performance by its modernising and harmonising in order to increase the capacity of the ATM network to cope with the ever-increasing number of flight operations while improving economic and security indicators $[2,14]$.

The current level of technical development of ATC and ATM systems has created the possibility of implementing a new way of flight planning method, leading to the abandonment of airways (Airways, AWY), and using only Waypoints (WP) to define the flight path. The airspace in the area where it will be possible to plan such a route is called the Free Route Airspace (FRA) [4]. The FRA concept will enable to match the path to aircraft performance better by optimising and minimising the differences between planned and operationally performed paths. It will also allow to improve the predictability of air traffic, which will reduce delays and consequently increase airspace capacity and improve air traffic efficiency indicators. The Polish Air Navigation Services Agency (PANSA) plans to launch the FRA airspace called POLFRA in the Polish airspace (FIR Warsaw) on February $28^{\text {th }}, 2019$ [12].

Preparing an appropriate flight plan has always been a difficult and demanding task due to the complexity of the airspace and the need to take into account the conditions and restrictions of different types. Path optimization is desirable and constitutes an added value. Currently, there 
are few companies on the market that have been involved in the development of computer flight planning systems (CFSPs) to meet the demand of airlines and other commercial users. However, CFSP systems are not widely available, mainly due to the high cost of their purchase. Therefore, there is a need to develop a simpler, widely available flight planning system, dedicated for non-commercial users (General Aviation, GA) and small commercial companies (Business Aviation, BA) as well as for flight planning of unmanned systems (Remotely Piloted Aircraft Systems, RPAS) [2, 14].

An essential part of the newly developed CFSP system will be the algorithm that can find the optimal path for an aircraft in the FRA for the given optimization criterion, taking into account the required restrictions and flight conditions.

The proper work of the algorithm will be possible if the proper set of input data and calculation models are available. Till today, the following minimum set of computational models has been identified: airspace model, trajectory model, aircraft model and model of the surrounding environment.

Currently there are no consistent models defining the emission of harmful substances in the aircrafts engines exhausts during the whole flight. There are relatively welldeveloped models that are capable of determining the emission of the aircraft in the take-off and landing phases (LTO). But there are no advanced models available for the full flight phase, which could be a standard. The need to determine flight paths characterized by the minimum emission of pollutants in the exhausts requires precise determination of aircraft emissions in all phases of the flight.

\section{Problem statement and research methodology}

In this paper the method of determination of harmful compounds present in exhaust gases emitted by a passenger aircraft engines is described - the proposed computational method is universal, i.e. it can be used for any jet communication and transport aircraft, if suitable technical data is available. The solution to the problem is illustrated on the example of the Gulfstream IV (Rolls-Royce Tay 611C) business jet aircraft.

The flight consists of 9 main successive stages:

1) taxi-out - means controlled movement of the aircraft on the apron, using its own propulsion, between the stopping point and the point from which the take-off will take place.

2) start - is the flight phase in which the airplane moves from the point of run-up on the runway and rises into the air.

3) departure from the airport and climb - includes the climb of the aircraft after take-off to the contractual moment when the aircraft reaches the altitude of $915 \mathrm{~m}$ $(3000 \mathrm{ft})$.

4) climb-out to the cruising altitude - is the phase of the flight, during which the aircraft climbs from $915 \mathrm{~m}$ to a fixed cruising altitude.

5) cruise - takes place between the stages of ascent and descent and is usually the longest stage of the journey. It ends when the plane approaches the destination, and the descent phase begins, and the plane prepares to land. During a cruise phase, for operational reasons or Air Traffic Control (ATC), planes can climb or descend from one flight level to a higher or a lower one. During very long flights, aircrafts are able to fly higher with the lower thrust required for flight, when the weight of fuel on board decreases. Usually, pilots ask ATC to allow them to fly at the optimum flight level for the aircraft they operate. This optimal level of flight depends, for example, on the type of aircraft, its operating mass and flight length. ATC generally accepts this request if it does not compromise safety. For most commercial passenger airplanes, most of the fuel is used in this phase of the flight.

6) descent - is the flight stage during which the airplane decreases its altitude during preparations to landing and is the opposite of the climb phase. Like climb, descent can be continuous or graduated for operational reasons or ATC; the continuous descent is the most fuel-efficient option. This phase lasts until the aircraft reaches a height of $915 \mathrm{~m}$.

7) approach to landing - is the final stage of the approach to the landing of the aircraft, occurs when the aircraft descends below $915 \mathrm{~m}$ and is in line with the runway and approaches the landing.

8) landing at the destination airport - is the flight stage when the plane returns to earth and continues until the plane is at the point where taxiing begins.

9) taxi-in - covers the movement of the aircraft on the ground, using its own propulsion, which takes place from the moment when the aircraft ends the run-out and runs to the stopping place from the runway and switches off the engines.

In the research, the Landing and Take-off Operations (LTO) were omitted, and the main attention was paid to the cruise stage. For the flight at a certain altitude and with certain velocity, the aircraft has a certain thrust requirements. This thrust depends on the altitude and velocity of the aircraft, its mass, aerodynamic parameters and lifting surface. The method of determining the thrust required for the flight was taken from [5]. The ambient parameters $(\mathrm{T}, \mathrm{p}, \rho)$ at a given altitude $\mathrm{H}$ can be computed from the dependences for the International Standard Atmosphere (ISA), where:

$$
\begin{gathered}
\mathrm{T}=\mathrm{T}_{\mathrm{o}} \cdot\left(1-\frac{\mathrm{H}}{44300}\right) \\
\mathrm{p}=\mathrm{p}_{\mathrm{o}} \cdot\left(1-\frac{\mathrm{H}}{44300}\right)^{5.356} \\
\rho=\frac{\mathrm{p}_{\mathrm{o}}}{\mathrm{T}_{\mathrm{o}} \cdot \mathrm{R}}
\end{gathered}
$$

where: $\mathrm{T}_{\mathrm{o}}, \mathrm{p}_{\mathrm{o}}$ - temperature and ambient pressure at the level of $\mathrm{H}=0[\mathrm{~m}]$ for the ISA $\left(\mathrm{T}_{\mathrm{o}}=288.15[\mathrm{~K}]\right.$ and $\mathrm{p}_{\mathrm{o}}=$ $101325[\mathrm{~Pa}]), \mathrm{R}-$ individual gas constant for air $(\mathrm{R}=287.2$ $[\mathrm{J} /(\mathrm{kg} \cdot \mathrm{K})]), \rho-$ air density $\left[\mathrm{kg} / \mathrm{m}^{3}\right]$.

In the next step, the lift coefficient for the known flight velocity is determined:

$$
\mathrm{C}_{\mathrm{z}}=\frac{2 \cdot \mathrm{Q}}{\mathrm{V}^{2} \cdot \rho \cdot \mathrm{S}}
$$

where: $\mathrm{Q}$ - aircraft weight determined from the formula: 


$$
\mathrm{Q}=\mathrm{m} \cdot \mathrm{g}
$$

$\mathrm{m}$ - mass of the plane $[\mathrm{kg}], \mathrm{g}-$ acceleration of gravity $\left[\mathrm{m} / \mathrm{s}^{2}\right], \mathrm{V}-$ flight velocity $[\mathrm{m} / \mathrm{s}], \mathrm{S}-$ lifting surface $\left[\mathrm{m}^{2}\right], \mathrm{C}_{\mathrm{z}}$ - lift coefficient [-].

Then, the drag coefficient is determined:

$$
\mathrm{C}_{\mathrm{x}}=0.015+0.08 \cdot \mathrm{C}_{\mathrm{z}}{ }^{2}
$$

With the coefficients $\mathrm{C}_{\mathrm{z}}$ and $\mathrm{C}_{\mathrm{x}}$, it is possible to determine the approximate value of power and thrust required for the flight:

$$
\begin{gathered}
P_{n}=\frac{C_{x}}{C_{z}} \cdot Q \cdot V \\
P_{n}=\frac{N_{n}}{V}
\end{gathered}
$$

where: $P_{n}-$ thrust required for the flight $[N], N_{n}-$ power required for the flight [W].

For the described methodology of computations and formulas given above the technical data of the Gulfstream IV aircraft was used and the results of the calculations are presented in the further part of the work. The following chart (Fig. 2) shows the thrust required for the flight as a function of the flight velocity [Ma] determined for the Gulfstream IV aircraft (for the altitude of 11,000 m).

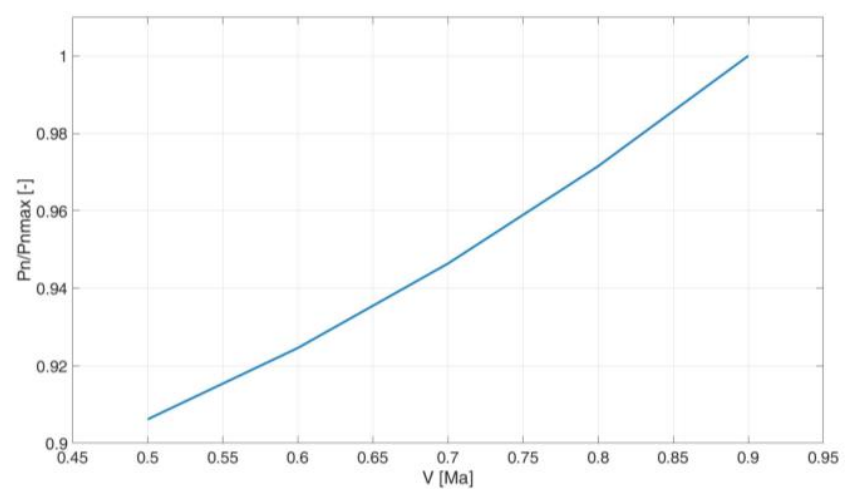

Fig. 2. Thrust required for the flight as a function of the flight velocity [Ma] determined for the Gulfstream IV aircraft (for the altitude of 11,000 m)

The range of engine run is selected in such a way to ensure a safe value of thrust for the flight. On the basis of the speed and altitude characteristics of the jet engine, the specific fuel consumption corresponding to a given thrust value can be given. These characteristics are determined experimentally (test bed aircrafts) or approximated in an analytical (computational) way.

Based on the available literature - manuals, engine catalogues, websites (e.g. [8]), the engine performance in the phase of LTO operation on the ground was read (Table 1). At the selected points, the thrust and the corresponding SFC were read and then a function between these points was approximated using a program written in the Matlab environment. The ground (rotational) characteristics of the engine was obtained, i.e. thrust and SFC as a function of rotations of the high pressure rotor. These characteristics are determined experimentally on the test benches (which are most often used and thus the analysis was based on such data) or by tedious and labour-intensive gas-dynamic com- putations, which give the results with an accuracy of up to $\pm 10 \%$ in relation to the actual engine run.

The methodology developed by the authors of the paper can be used to determine the engine thrust and SFC during the flight. The correct determination of engine performance during the flight is very important when determining the emission of pollutants in the engine exhausts, it is however often treated in a vague or imprecise way in some articles.

To determine the speed-altitude characteristics of the engine based on its rotational characteristics, it is necessary to reduce the engine performance parameters at ground level. The formula for the engine thrust is as follows [1]:

$$
\mathrm{K}=\mathrm{m}^{\prime} \cdot \mathrm{c}_{5}-\dot{\mathrm{m}} \cdot \mathrm{V}
$$

where: $\mathrm{m}^{\prime}$ - exhausts mass flow $[\mathrm{kg} / \mathrm{s}], \dot{\mathrm{m}}$ - mass flow of the air intake by the engine $[\mathrm{kg} / \mathrm{s}], \mathrm{c}_{5}-$ exhaust gas velocity in the nozzle $[\mathrm{m} / \mathrm{s}], \mathrm{V}-$ aircraft flight velocity $[\mathrm{m} / \mathrm{s}]$.

For ground characteristics, where $\mathrm{V}=0[\mathrm{~km} / \mathrm{h}]$ the thrust is described by the formula [1]:

$$
\mathrm{K}_{\mathrm{o}}=\mathrm{m}^{\prime} \cdot \mathrm{c}_{5}
$$

The first thing to determine are the parameters of the environment at a given flight velocity and flight altitude. To determine total temperature and total pressure at a given flight altitude and velocity, there can be used the following formulas:

$$
\begin{gathered}
\mathrm{T}_{\mathrm{c}}=\mathrm{T}_{\mathrm{o}} \cdot\left(1+0.2 \cdot \mathrm{Ma}^{2}\right) \\
\mathrm{p}_{\mathrm{c}}=\mathrm{p}_{\mathrm{o}} \cdot\left(1+0.2 \cdot \mathrm{Ma}^{2}\right)^{3.5}
\end{gathered}
$$

where: $\mathrm{T}_{\mathrm{c}}, \mathrm{p}_{\mathrm{c}}-$ total temperature $[\mathrm{K}]$ and total pressure (dynamic pressure and temperature) $[\mathrm{Pa}], \mathrm{T}_{0}, \mathrm{p}_{\mathrm{o}}$ - ambient temperature $[\mathrm{K}]$ and ambient pressure $[\mathrm{Pa}]$ at a given flight altitude (according to the ISA), Ma - velocity of the plane [in Mach].

Having the value of a thrust at sea level, it is possible to determine a thrust for a known flight altitude and flight velocity [1]:

$$
\mathrm{K}=\mathrm{K}_{\mathrm{o}} \cdot \frac{\mathrm{p}_{\mathrm{c}}}{101325[\mathrm{~Pa}]}-\dot{\mathrm{m}}_{\mathrm{c}} \cdot \mathrm{V}
$$

where: $\dot{m}_{c}-$ reduced mass air flow, determined from the formula:

$$
\dot{\mathrm{m}}_{\mathrm{c}}=\dot{\mathrm{m}}_{\mathrm{o}} \cdot\left(\frac{101325[\mathrm{~Pa}]}{\mathrm{p}_{\mathrm{c}}} \cdot \sqrt{\frac{\mathrm{T}_{\mathrm{c}}}{288.15[\mathrm{~K}]}}\right)^{-1}
$$

where: $\dot{\mathrm{m}}_{\mathrm{o}}-$ mass flow at $\mathrm{H}=0[\mathrm{~m}]$ and $\mathrm{V}=0[\mathrm{~m} / \mathrm{s}]$.

The specific fuel consumption can be computed from:

$$
\mathrm{SFC}=\mathrm{SFC}_{\mathrm{o}} \cdot \sqrt{\frac{288.15[\mathrm{~K}]}{\mathrm{T}_{\mathrm{C}}}}
$$

where: $\mathrm{SFC}_{\mathrm{o}}$ - specific fuel consumption $[\mathrm{kg} /(\mathrm{N} \cdot \mathrm{h})]$ at $\mathrm{H}=$ $0[\mathrm{~m}]$ and $\mathrm{V}=0[\mathrm{~m} / \mathrm{s}]$.

The chart below (Fig. 3) shows the approximated speed and altitude characteristic of the Rolls-Royce Tay 611C jet engine determined at $11,000 \mathrm{~m}$ by the authors of this paper, applying the universal methodology described in the paper. 


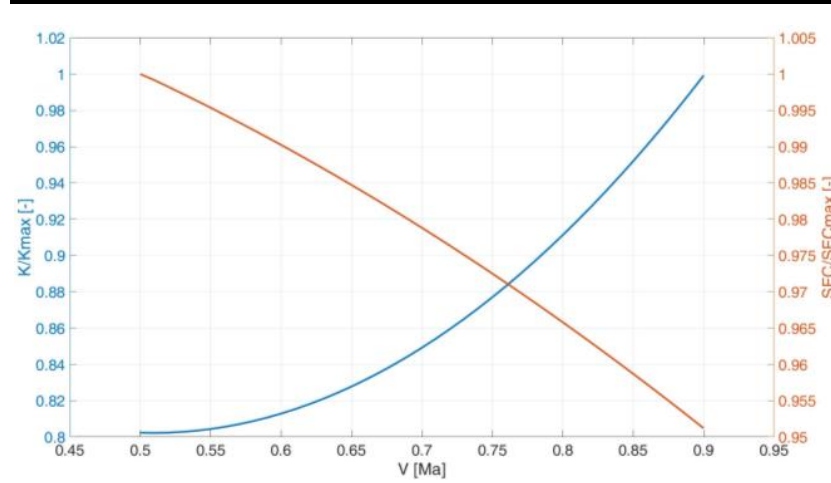

Fig. 3. Approximated speed and altitude characteristic of the Rolls-Royce Tay $611 \mathrm{C}$ jet engine (determined for the altitude of $11,000 \mathrm{~m}$ )

The next chart (Fig. 4) shows the thrust curve of the two Rolls-Royce engines and a curve of the thrust required for the flight. The range between these curves is the manoeuvring range (it is possible to make adjustments to the thrust of the engines and use a higher engine power for the flight).

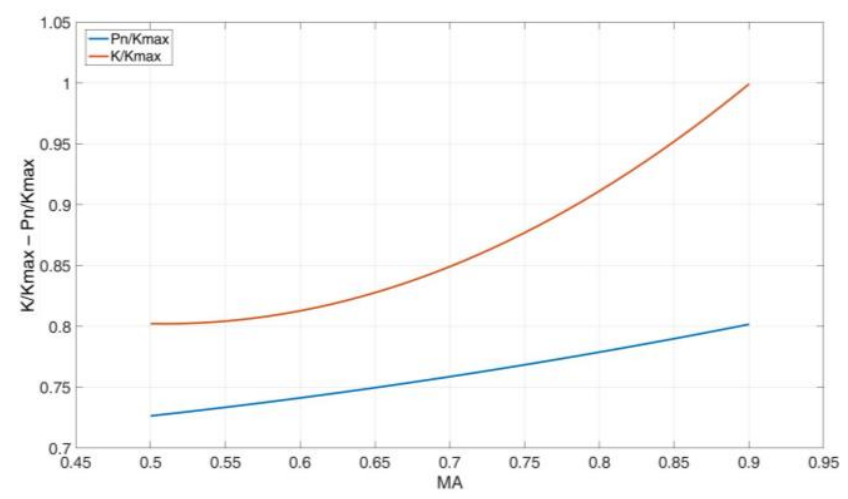

Fig. 4. A curve of thrust of two Rolls-Royce Tay $611 \mathrm{C}$ jet engines and a curve of the thrust required for the flight

Knowing the engines performance corresponding to the given flight stage, the emission of harmful compounds in exhausts of jet engines (e.g. $\mathrm{NO}_{\mathrm{x}}, \mathrm{HC}, \mathrm{CO}$ ) can be determined. To determine these emission, there can be used the following formulas:

$$
\begin{aligned}
\mathrm{E}_{\mathrm{CO}} & =\mathrm{EI}_{\mathrm{CO}} \cdot 10^{-3} \cdot \mathrm{K} \cdot \mathrm{SFC} \cdot \mathrm{t} \cdot \mathrm{l} \\
\mathrm{E}_{\mathrm{NOx}} & =\mathrm{EI}_{\mathrm{NOx}} \cdot 10^{-3} \cdot \mathrm{K} \cdot \mathrm{SFC} \cdot \mathrm{t} \cdot \mathrm{l} \\
\mathrm{E}_{\mathrm{HC}} & =\mathrm{EI}_{\mathrm{HC}} \cdot 10^{-3} \cdot \mathrm{K} \cdot \mathrm{SFC} \cdot \mathrm{t} \cdot \mathrm{l}
\end{aligned}
$$

where: $\mathrm{E}_{\mathrm{CO}} / \mathrm{E}_{\mathrm{NOx}} / \mathrm{E}_{\mathrm{HC}}$ - emission of particular compounds in exhausts [kg], $\mathrm{EI}_{\mathrm{CO}} / \mathrm{EI}_{\mathrm{NOx}} / \mathrm{EI}_{\mathrm{HC}}$ - emission factors for particular substances, depended on the type of engine and the range of its run $[\mathrm{g} / \mathrm{kg}], \mathrm{K}-$ engine thrust $[\mathrm{N}], \mathrm{SFC}-$ specific fuel consumption $[\mathrm{kg} /(\mathrm{N} \cdot \mathrm{h})], \mathrm{t}$ - engine run time at a given thrust $[\mathrm{h}], 1$ - number of engines.

Due to the fact that the formation of some compounds $\left(\mathrm{CO}_{2}, \mathrm{H}_{2} \mathrm{O}\right.$ and $\left.\mathrm{SO}_{2}\right)$ as a result of fuel combustion by aircraft engines is directly proportional to the amount of fuel consumed, modelling emissions of these compounds requires only the knowledge of the fuel consumption and emission factors for a given fuel. The formula of the carbon dioxide emission $[\mathrm{kg}]$ is as follows:

$$
\mathrm{E}_{\mathrm{CO}_{2}}=3.15 \cdot \mathrm{K} \cdot \mathrm{SFC} \cdot \mathrm{t} \cdot \mathrm{l}
$$

The problem in determination of emission during cruise stage is the lack of information concerning emission factors (EI) for toxic compounds in jet engine exhausts. These coefficients are determined experimentally for landing and take-off operations (LTO) and depend on the engine construction, as well as its load (range of cruising power). Engine power settings and times-in-mode for a given LTO cycle are specified by ICAO [6], as shown in Table 1.

Table 1. Engine power settings and times-in-mode for the LTO cycle specified by ICAO [6]

\begin{tabular}{|l|c|c|}
\hline LTO cycle & Thrust range $\left[\%\right.$ Foo $\left.^{*}\right]$ & Cycle time $[\mathrm{min}]$ \\
\hline Take-off $(\mathrm{T} / \mathrm{O})$ & 100 & 0.7 \\
\hline Climb-out $(\mathrm{C} / \mathrm{O})$ & 85 & 2.2 \\
\hline Approaching $(\mathrm{App})$ & 30 & 4.0 \\
\hline Taxi (Idle) & 7 & 26 \\
\hline
\end{tabular}

*Foo - rated thrust

Each engine has different emission factors. The values of these emission factors can be found in the available ICAO databases. For example, for the Rolls Royce Tay 611C engine, EI of emitted pollutants for LTO determined for the engine power settings and times-in-mode, are shown in Table 2.

Table 2. Emission factors for RR Tay $611 \mathrm{C}$

\begin{tabular}{|l|c|c|c|c|}
\hline & T/O & C/O & App & Idle \\
\hline $\begin{array}{l}\mathrm{EI}_{\text {NOxLTO }} \\
{[\mathrm{g} / \mathrm{kg}]}\end{array}$ & 9.93 & 9.79 & 5.23 & 1.08 \\
\hline $\begin{array}{l}\mathrm{EI} \\
\text { HCLTO } \\
{[\mathrm{g} / \mathrm{kg}]}\end{array}$ & 0 & 0.67 & 16.0 & 96.67 \\
\hline $\begin{array}{l}\mathrm{EI} \\
\text { COLTO } \\
{[\mathrm{g} / \mathrm{kg}]}\end{array}$ & 2.52 & 4.18 & 49.24 & 124.60 \\
\hline
\end{tabular}

It is worth noticing that no EI coefficients are given for the remaining flight stages. The authors of the paper, based on the literature [7, 13], have determined these emission factors for a given moment of flight, i.e., for the engine thrust and external conditions affecting the engine run. Emission indexes corresponding to the appropriate range of engine run during the LTO cycle must be reduced taking into account the change in ambient pressure and ambient temperature due to higher altitude and flight velocity. These formulas for the reduced emission indexes are as follows [13]:

$$
\begin{gathered}
\mathrm{EI}_{\mathrm{CO}}=\mathrm{EI}_{\text {COLTO }} \cdot \frac{\theta^{3.3}}{\delta^{1.02}} \\
\mathrm{EI}_{\mathrm{HC}}=\mathrm{EI}_{\text {HCLTO }} \cdot \frac{\theta^{3.3}}{\delta^{1.02}} \\
\mathrm{EI}_{\mathrm{NOx}}=\mathrm{EI}_{\text {NOxLTO }} \cdot \sqrt{\frac{\delta^{1.02}}{\theta^{3.3}}} \cdot \mathrm{e}^{\mathrm{h}}
\end{gathered}
$$

where: $\mathrm{EI}_{\mathrm{CO}}, \mathrm{EI}_{\mathrm{HC}}, \mathrm{EI}_{\mathrm{NOx}}-\mathrm{CO}, \mathrm{HC}$ and $\mathrm{NO}_{\mathrm{x}}$ emission indexes at a given altitude $[\mathrm{g} / \mathrm{kg}], \mathrm{EI}_{\text {COLTO }}, \mathrm{EI}_{\text {HCLTO }}$, $\mathrm{EI}_{\text {NOXLTO }}-\mathrm{CO}, \mathrm{HC}$ and $\mathrm{NO}_{\mathrm{x}}$ emission indexes measured for LTO parameters $[\mathrm{g} / \mathrm{kg}], \theta-$ temperature change coefficient [-]: 


$$
\theta=\frac{\mathrm{T}_{\mathrm{c}}}{288.15 \mathrm{~K}}
$$

$\delta$ - pressure change coefficient $[-]$ :

$$
\delta=\frac{\mathrm{p}_{\mathrm{c}}}{101325 \mathrm{~Pa}}
$$

$\mathrm{e}-$ Euler number $(\mathrm{e}=2.72), \mathrm{h}$ - air humidity factor depended on the altitude [-],

$$
\mathrm{h}=-19 \cdot(\omega-0,00634)
$$

$\omega$ - specific humidity, where

$\omega=10^{-3} \cdot \mathrm{e}^{-0,0001426 \cdot(\mathrm{H}-12900)}$ for ISA,

where $\mathrm{H}-$ is the cruising altitude given in feet.

In the last step, the obtained emission factors for the cruise phase should be substituted to the formulas (16)(18). In this way, knowing the flight duration, there can be determined the emission of $\mathrm{CO}, \mathrm{HC}$ and $\mathrm{NO}_{\mathrm{x}}$ for a given altitude and flight velocity, as well as the mean mass of the emitted pollutants at a given route section, e.g. $1 \mathrm{~km}$, and mean emission intensity of a given pollutant, as shown in Tables 3 and 4 .

\section{Results and discussion}

In Table 3 there are shown the obtained results of the average emission intensity $[\mathrm{kg} / \mathrm{h}]$ of selected harmful compounds emitted in exhausts during the cruise phase on a route of $1000 \mathrm{~km}$ for the studied aircraft (Gulfstream IV) at known altitude and flight velocity.

It is worth noting that the presented methodology for determining the aircraft's performance and emission of pollutants in the exhausts of its engines is universal and can be used for any other jet aircraft.

Table 3. Emission intensity [in $\mathrm{kg}$ of $\mathrm{CO}, \mathrm{HC}, \mathrm{NO}_{\mathrm{x}}, \mathrm{CO}_{2}$ per 1 hour of flight]

\begin{tabular}{|c|c|c|c|c|c|}
\hline $\begin{array}{c}\text { Cruising } \\
\text { altitude }\end{array}$ & $\mathrm{Ma}$ & $\dot{\mathrm{E}}_{\mathrm{CO}}\left[\frac{\mathrm{kg}}{\mathrm{h}}\right]$ & $\dot{\mathrm{E}}_{\mathrm{HC}}\left[\frac{\mathrm{kg}}{\mathrm{h}}\right]$ & $\dot{\mathrm{E}}_{\mathrm{NOx}}\left[\frac{\mathrm{kg}}{\mathrm{h}}\right]$ & $\dot{\mathrm{E}}_{\mathrm{CO} 2}\left[\frac{\mathrm{kg}}{\mathrm{h}}\right]$ \\
\hline \multirow{3}{*}{$9000 \mathrm{~m}$} & 0.7 & 3.7750 & 0.4854 & 60.9380 & 5452 \\
\cline { 2 - 6 } & 0.8 & 3.8397 & 0.4937 & 62.6622 & 5586 \\
\cline { 2 - 6 } & 0.9 & 4.0309 & 0.5183 & 66.5783 & 5912 \\
\hline \multirow{3}{*}{$10,000 \mathrm{~m}$} & 0.7 & 3.9646 & 0.5097 & 58.5721 & 5395 \\
\cline { 2 - 6 } & 0.8 & 4.0385 & 0.5192 & 60.3186 & 5536 \\
\cline { 2 - 6 } & 0.9 & 4.2509 & 0.5465 & 64.2582 & 5874 \\
\hline \multirow{3}{*}{$11,000 \mathrm{~m}$} & 0.7 & 2.9772 & 0.2977 & 62.9360 & 5335 \\
\cline { 2 - 6 } & 0.8 & 3.0375 & 0.3037 & 64.9165 & 5483 \\
\cline { 2 - 6 } & 0.9 & 3.0876 & 0.3088 & 66.7853 & 5618 \\
\hline
\end{tabular}

When considering changes in emission of the selected pollutants with regard to the changes of cruising velocity and cruising altitude, it can be noted that the higher the cruising velocity, the lower the $\mathrm{CO}_{2}$ emission, which is caused by the lower fuel consumption.

At the cruising altitudes of 9 and $10 \mathrm{~km}$, the engine works at a similar load, but gives different thrust values (with the increasing altitude the thrust decreases) at different emission factors. This results in lower $\mathrm{NO}_{\mathrm{x}}$ emission and higher $\mathrm{CO}$ and $\mathrm{HC}$ emission at $10 \mathrm{~km}$ compared to the one at $9 \mathrm{~km}$. However, at the height of $11 \mathrm{~km}$, the engine load increases, which leads to the change in EI, thrust and SFC values (as the altitude increases, the thrust decreases, the SFC increases but fuel consumption decreases). This in turn means that despite the reduction of $\mathrm{CO}_{2}$ emissions (which results from the lower fuel consumption), as well as the reduction of $\mathrm{CO}$ and $\mathrm{HC}$ emissions, the $\mathrm{NO}_{\mathrm{x}}$ emission increases.

It can also be noted that higher cruising velocity of the aircraft at a given cruising altitude results in higher emission intensity of all pollutants considered.

In Table 4 there are shown the obtained results of the average emission $[\mathrm{kg} / \mathrm{km}]$ of selected harmful compounds emitted in exhausts during the cruise phase on a route of $1000 \mathrm{~km}$ for the studied aircraft (Gulfstream IV) at known altitude and flight velocity.

Table 4. Emission [in $\mathrm{kg}$ of $\mathrm{CO}, \mathrm{HC}, \mathrm{NO}_{\mathrm{x}}, \mathrm{CO}_{2}$ per $1 \mathrm{~km}$ of flight]

\begin{tabular}{|c|c|c|c|c|c|}
\hline \multirow{2}{*}{$\begin{array}{c}\text { Cruising } \\
\text { altitude }\end{array}$} & $\mathrm{Ma}$ & $\mathrm{E}_{\mathrm{CO}}\left[\frac{\mathrm{kg}}{\mathrm{km}}\right]$ & $\mathrm{E}_{\mathrm{HC}}\left[\frac{\mathrm{kg}}{\mathrm{km}}\right]$ & $\mathrm{E}_{\mathrm{NOx}}\left[\frac{\mathrm{kg}}{\mathrm{km}}\right]$ & $\mathrm{E}_{\mathrm{CO} 2}\left[\frac{\mathrm{kg}}{\mathrm{km}}\right]$ \\
\cline { 2 - 7 } & 0.7 & 0.004931927 & 0.000634161 & 0.079613715 & 7.122878538 \\
\hline \multirow{2}{*}{$9000 \mathrm{~m}$} & 0.8 & 0.004389399 & 0.000564379 & 0.071633040 & 6.385702416 \\
\cline { 2 - 7 } & 0.9 & 0.004095975 & 0.000526667 & 0.067653135 & 6.007442843 \\
\hline \multirow{2}{*}{$10,000 \mathrm{~m}$} & 0.7 & 0.005254596 & 0.000675546 & 0.077630213 & 7.150418042 \\
\cline { 2 - 7 } & 0.8 & 0.004683474 & 0.000602120 & 0.069951864 & 6.420134383 \\
\cline { 2 - 7 } & 0.9 & 0.004382041 & 0.000563360 & 0.066240571 & 6.055213450 \\
\hline \multirow{2}{*}{$11,000 \mathrm{~m}$} & 0.7 & 0.004004727 & 0.000400446 & 0.084657232 & 7.176279599 \\
\cline { 2 - 7 } & 0.8 & 0.003575109 & 0.000357452 & 0.076406108 & 6.453439253 \\
\hline \multirow{2}{*}{} & 0.9 & 0.003230290 & 0.000323071 & 0.069871705 & 5.877629314 \\
\hline
\end{tabular}

Considering changes in emissions of tested pollutants depending on the change in cruising altitude, it can be noted that $\mathrm{CO}$ and $\mathrm{HC}$ emissions at $11 \mathrm{~km}$ reach lower values than those at 9 and $10 \mathrm{~km}$. However, as the altitude increases, the engine load increases, which leads to an increase in $\mathrm{NO}_{\mathrm{x}}$ emissions. In turn, with the increase of cruising altitude, $\mathrm{CO}_{2}$ emissions decrease, which is caused by lower fuel consumption.

It can also be noted that as the flight velocity increases, emissions per one kilometre of all harmful substances are reduced - flight velocity is of great importance. With the increase of cruising velocity, the time to cover the same route (e.g. $100 \mathrm{~km}$ ) is significantly shortened.

The engine load increases by several percent in line with the increase of the cruising velocity (from 0.7 to 0.9 Ma) which, combined with the shorter flight time on a given route, means that the average emission per kilometre is lower.

\section{Conclusions}

The paper describes an effective method of determination of pollutants emitted in a passenger aircraft engines exhausts during the cruise phase. For the research purposes, the Gulfstream IV (Rolls-Royce Tay 611C) business jet aircraft was taken. However, this computational method is universal and can be used for any jet communication and transport aircraft (for which suitable technical data is available) in order to compute the emission of different pollutants in the exhausts of its engines, generated on a given route (in cruise phase).

The obtained results indicate that any change in the ambient conditions during engine operation (caused by a change in altitude and flight speed) significantly affects the emission of pollutants in the engine exhausts. It can be noticed that with the increase in cruising altitude, the emission of $\mathrm{CO}, \mathrm{HC}$ and $\mathrm{CO}_{2}$ decreases, while the $\mathrm{NO}_{\mathrm{x}}$ emission increases. However, when the same flight level is considered, there can be noticed that with the increase of the flight 
speed, the emission of harmful compounds in the exhaust increases. The developed method can be used for similar analyses for other jet passenger aircrafts.
This project has received funding from the SESAR Joint Undertaking under the European Union's Horizon 2020 research and innovation programme under grant agreement No 734129.

\section{Bibliography}

[1] CICHOSZ, E., KORDZIŃSKI, W., ŁYŻWIŃSKI, M., SZCZECIŃSKI, S. Charakterystyka i zastosowanie napędów - napędy lotnicze. Wydawnictwa Komunikacji i Łączności, Warszawa 1980.

[2] EUROCONTROL webpage, www.eurocontrol.int

[3] EUROCONTROL, Flight movements and service units 2016-2022, EUROCONTROL Seven-Year Forecast, European organisation for the Safety of Air Navigation, February 2016.

[4] EUROCONTROL, Free route airspace developments. For a route-free European network, European Organisation for the Safety of Air Navigation, 2016.

[5] FISZDON, W. Mechanika lotu, PWN, Warszawa, 1964.

[6] ICAO, Convention on International Civil Aviation, Annex 16 : Environmental Aviation, Volume II: Aircraft Engine Emissions, International Civil Aviation Organization, Third Edition, July 2008.

[7] ICAO emission databank, https://www.easa.europa.eu/easaand-you/environment/icao-aircraft-engine-emissionsdatabank

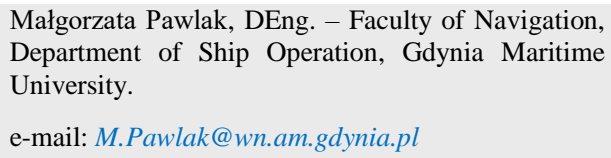

Michał Kuźniar, MEng. - Faculty of Mechanical Engineering and Aeronautics, Rzeszow University of Technology.

e-mail:MKuzniar@prz.edu.pl
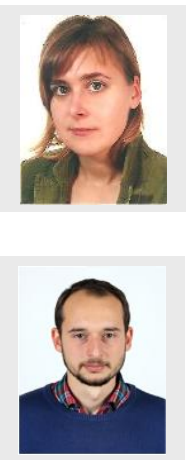

[8] Jet Engine specification database, jet-engine.net

[9] KOPECKI, G., PECZKOWSKI, M., ROGALSKI, T. Przykładowy algorytm wyznaczania trasy przelotu w przestrzeni lotów swobodnych. Autobusy. 2017, 6 .

[10] KRZYŻANOWSKI, M. Conflict free and efficient flight routes planning in free route airspace. Prace Naukowe Politechniki Warszawskiej, Transport, z. 95, Warszawa 2013.

[11] MALARSKI, M. Inżynieria ruchu lotniczego, Oficyna Wydawnicza Politechniki Warszawskiej, Warszawa 2006.

[12] Polska Agencja Żeglugi Powietrznej, PAŻP webpage, www.pansa.pl

[13] SCHAEFER, M., BARTOSCH, S. Overview on fuel flow correlation methods for the calculation of $\mathrm{NO}_{\mathrm{x}}, \mathrm{CO}$ and $\mathrm{HC}$ emissions and their implementation into aircraft performance software, Interner Bericht Deutsches Zentrum für Luft- und Raumfahrt (DLR). Institut für Antriebstechnik, Köln, 2013.

[14] SESAR JU webpage, www.sesarju.eu

[15] SKORUPSKI, J. Współczesne problemy inżynierii ruchu lotniczego. Modele i metody. Praca zbiorowa. Oficyna $W y$ dawnicza Politechniki Warszawskiej, Warszawa 2014.

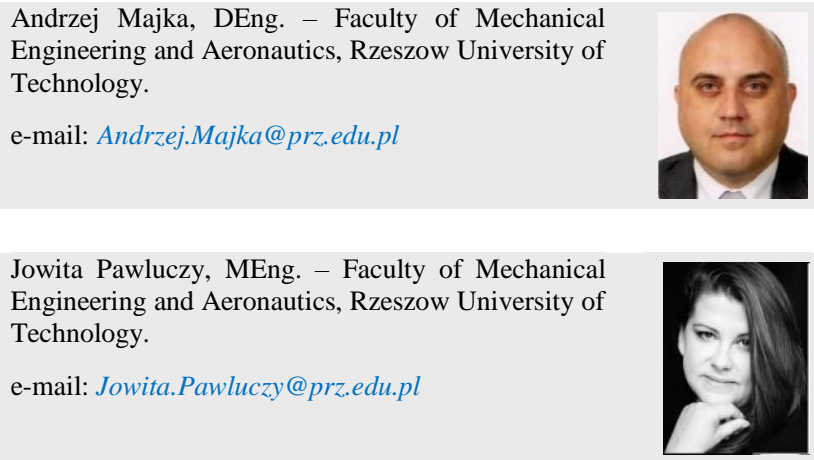

Engineering and Aeronautics, Rzeszow University of 